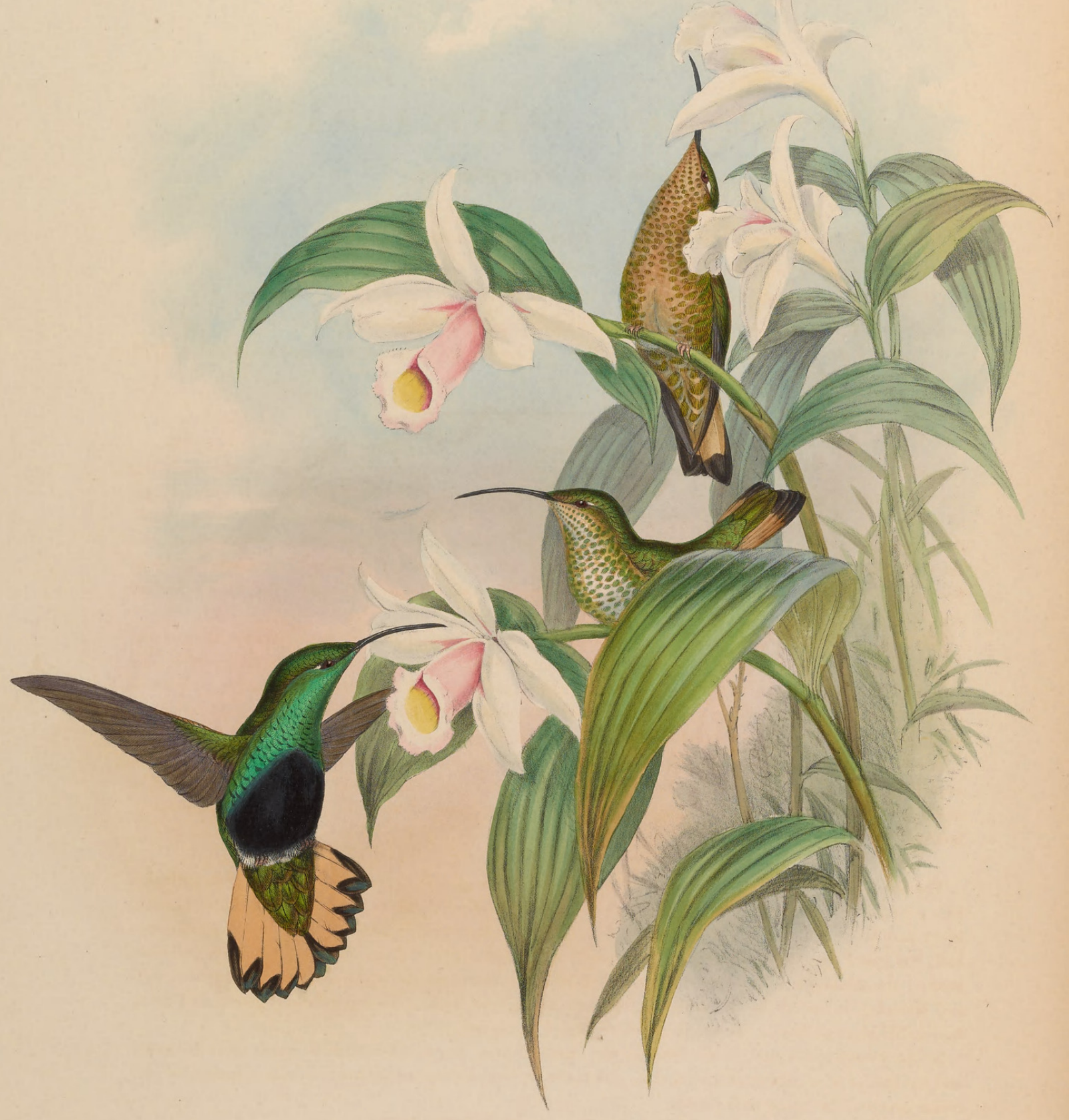




\section{LAFRESNAYA FLAVICAUDATA.}

\section{Buff-tailed Velvet-breast.}

Trochilus flavicaudatus, Fras. in Proc. of Zool. Soc., part viii. p. 18.

Lafresnayi, Boiss. Rev. Zool. 1848, p. 8.

Calothorax Lafresnayi, Gray and Mitch. Gen. of Birds, vol. i. p. 110, Calothorax, sp. 1.

Lafresnaya flavicaudatus, Bonap. Consp. Gen. Av., p. 68, Lafresnaya, sp. 1.

flavicaudata, Reich. Aufz.der Col., p.11.-Bonap. Rev. et Mag. de Zool.1854, p. 252.

Noт only are the Columbian Andes most fertile in species of Humming-birds, but, in many instances, forms there occur which do not exist elsewhere; and the genus Lafresnaya may be cited as one of such genera, of which two, if not three, well-defined species have been discovered, and which are true Andean birds. Although the extent of the range enjoyed by the present species has not been accurately ascertained, we know that it plays a conspicuous part in bird-life in the neighbourhood of Bogota and other parts of Columbia. I have not, however, seen specimens from Popayan, Quito, or Ecuador, yet M. Warszewicz collected examples in Peru, a country still farther south.

It will be seen that the present bird has been twice described, and it is to be regretted that the name of Lafresnayi cannot be retained as its specific appellation, as no one is more worthy of having a beautiful bird dedicated to him than the worthy and amiable Baron de la Fresnaye: his name will, however, in spite of this contretemps, be handed down to posterity not only as the author of many valuable papers on Ornithology, but as the individual in honour of whom the present genus has been entitled Lafresnaya.

The females, and especially the young males, of this species present a beautifully spangled character of markings, which become most glittering and attractive when the breasts of the birds are so placed as to receive the direct rays of light, and contrast strongly when compared with the green throat and velvety breast of the male.

The male has the crown of the head, all the upper surface, wing-and upper tail-coverts dark green ; wings rich purplish-brown; throat, breast, upper part of the abdomen and flanks very dark shining grass-green; lower part of the abdomen velvety-black; two central tail-feathers of a bronzy hue, the remainder yellowishbuff; the apical two-thirds of the outer web, and the tip of the inner web, of the external feather purplishbrown ; the remainder with an arrow-shaped mark of bronzy-brown at the tip, broadest on the external web, and lessening in extent as the feathers approach the centre; under tail-coverts bronzy-green, with white bases; bill blackish-brown, the under mandible somewhat lighter.

In the young males, and in the females, the bronze tipping to the tail-feathers is much more extensive, and the buff is of a somewhat deeper tint; the under surface is white, or buffy-white, with a spangle of glittering green at the tip of each feather.

Both sexes are figured on the accompanying Plate, on the Sobralia sessilis. 


\section{$2 \mathrm{BHL}$ Biodiversity Heritage Library}

Gould, John. 1853. "Lafresnaya flavicaudata, Buff-tailed Velvet-breast. [PI. 85]." A monograph of the Trochilidae, or family of humming-birds 2, https://doi.org/10.5962/p.316894.

View This Item Online: https://www.biodiversitylibrary.org/item/108332

DOI: https://doi.org/10.5962/p.316894

Permalink: https://www.biodiversitylibrary.org/partpdf/316894

\section{Holding Institution}

Smithsonian Libraries

\section{Sponsored by}

Smithsonian Institution Libraries

\section{Copyright \& Reuse}

Copyright Status: NOT_IN_COPYRIGHT

This document was created from content at the Biodiversity Heritage Library, the world's largest open access digital library for biodiversity literature and archives. Visit BHL at https://www.biodiversitylibrary.org. 